International Journal of Agriculture, Environment and Bioresearch

Vol. 4, No. 04; 2019

ISSN: $2456-8643$

\title{
USE OF THYMUS VULGARIS IN HENS GALLUS GALLUSDOMESTICUS DE BACKYARD; AN APPROACH TO THE SOLUTION OF COCCIDIOSIS
}

\author{
Ana Karen González-Mendoza ${ }^{1}$; Cadena-Iñiguez, P. $^{2}$; Zaragoza-Martínez, M de L. ${ }^{3}$; Ponce-Díaz P. ${ }^{3}$ and \\ Reyes-García, M.E. ${ }^{4}$ \\ ${ }^{1}$ Student Of Master's In Sciences of the Autonomous University of Chiapas, Master of Science in Tropical \\ Agricultural Production \\ ${ }^{2}$ Researcher of the National Institute of Forestry, Agriculture and Livestock Research. Km 3 Road Ocozocoautla- \\ Cintalapa, Ocozocoautla de Espinosa, Chiapas CP. 29140 \\ ${ }^{3}$ Professor-Researchers of the Autonomous University of Chiapas, Boulevard Belisario Domínguez, Kilómetro 1081, \\ Sin Número, Terán Tuxtla Gutiérrez, Chiapas, México, C.P. 29050 \\ http://doi.org/10.35410/IJAEB.2019.4416
}

\begin{abstract}
The present work represents an advance in the state of the art to counteract the presence of Eimeria spp, in birds reared under the conditions of backyard production systems in the state of Chiapas, in a municipality very close to the economic capital of the state. The literature review shows the effectiveness of thymol extracted from thyme Thymus vulgaris to minimize the presence of coccidia which would help in the backyard farms, to the families that own these birds to consume or commercialize chickens standing or free of this disease, without representing a danger to public health.
\end{abstract}

Keywords: coccidiosis, timol, Chiapas, Mexico .

\section{INTRODUCTION}

The number of poultry has grown dramatically worldwide, approximately $80 \%$ of rural households in developing countries breed poultry (FAO, 2019), because it is considered the production of Creole chickens Gallus gallusdomesticus as a very viable productive activity, since these birds show good resistance to diseases and high capacity to adapt to climatic conditions (Guevara, 2014). In Mexico, more than $75 \%$ of rural families practice family poultry farming as one of the main sources of animal protein for families (Zaragoza et al., 2014).

The main bird-producing countries are the United States, China, Brazil, India, Russia and occupying the sixth place, Mexico (UNA, 2016); However, the problem that exists around the production of Creole chickens and the production of these in an intensive manner, highlights the protozoan Eimeria genus that causes coccidiosis, one of the most common diseases of birds. The economic effects are dramatic since in addition to producing severe injuries to the intestines and retarded the development and weight of the birds, it can kill all the animals in the production system. The economic repercussions are difficult to quantify, however, it is estimated that only 
the costs of the medication used in its control in the USA exceed 90 million dollars and in the rest of the world more than 300 million dollars (Alcaíno, 2002).

Chiapas, a Mexican state in the southeast of the republic, has a production of 31,061 tons of accumulated light and heavy hens standing until February 2019 and 137 tons of turkeys standing. It is ranked seventh nationally in poultry production (SIAP, 2019) because these species have a short generation interval and under the geographical and environmental conditions of the region show a high rate of productivity.

However, in Chiapas, most of the rural or backyard farms lack proper sanitary management such as: cleaning and disinfestation of feeders and drinking fountains, cleaning of poultry houses, administration of drinking water, balanced meals, vaccination schedules and deworming, which leads to poor health management and consequently, animals tend to suffer from various parasitic diseases mainly.

In Mexico there have been few studies on deworming with plant extracts which have been mainly focused on ruminants, however, works published in Morocco, Ecuador and other countries indicate the effectiveness of natural plant extracts in the treatment of coccidiosis, in which was determined the complete deworming of oocysts of EimeriaSpp. in parasitized birds (Paredes, 2015).

The production of the birds at the backyard level means an economic and social support for the small producers, because it reduces the expense of the family for the purchase of meat and is a means to transform the waste and surplus of grains, nevertheless, The free-form backyard hen production system directly influences the biological cycle of the parasites, mainly of Eimeria spp., affecting the production of hens.

Ruíz and Mendoza (2014) mention that sanitary management in rural farms in Chiapas is neglected, so that animals suffer from diseases and is correlated with that $63 \%$ of producers do not use deworming and $68 \%$ present problems of mortality in the flock. Consequently, the birds do not express their genetic potential, with which their production and health decrease and increase the morbidity, mortality and feed conversion rates, which results in economic losses to the producers.

The use of coccidiostats allows a good development of the birds, but EimeriaSpp. shows resistance to certain drugs, particularly ionophores such as monensin, lasalocid, salinomycin, narasin and maduramicin, in addition to the byproducts such as eggs and meat can not be consumed without a period of previous withdrawal of the active principle and also can be toxic and lethal for turkeys, therefore, it is important to read the label before administering them (Roberts, 2013).

The form of control of avian coccidiosis is essentially based on the use of synthetic drugs and through vaccination, which can be performed from several methods, with the oral route being the main form of administration, of various attenuated species of Eimeria. With respect to the use of vaccines, the sanitary control organisms in some countries do not authorize the introduction of vaccines containing Eimeria species that do not exist in the country, since, being live vaccines, 
Vol. 4, No. 04; 2019

ISSN: $2456-8643$

their use can mean a risk of introducing the species. In order to regulate the use of medicinal compounds used in the poultry industry, the European Union banned a long list of products with coccidiostatic effect and as the regulation is becoming stricter, it is necessary to look for new forms of control (Roberts et al. ., 2013).

Coccidiosis is a common disease of birds, caused by protozoa of the genus Eimeria that seriously affect the health and productivity of the production system. Infection by Eimeria is transmitted when the oocyst falls to the ground, it sporulates and remains viable for a time; High humidity and high temperature of the bed or soil are considered optimal conditions. Sporozoites are the infective forms found in oocysts and can continue their biological cycle when a chicken ingests them (Del Cacho, 2013). Poultry farmers usually fight against this disease using various disinfectants against oocysts and administering treatments to animals with antiparasitic drugs; however, the sanitary aspects influence and currently the protozoa of the genus Eimeria have resistance to different coccidiostats and coccidiocides (Roberts, 2013).

Mexico is a country that possesses high biodiversity and the exploitation of natural products leads to scientific and technological development, as well as to a social and economic development that generates work sources. Thus, the use of essential oils becomes important in medicine, nutrition and control of agricultural pests, because it is a very viable alternative both from an economic and social point of view. (Cano, 2001).

\section{USES OF ESSENTIAL OILS}

The search for new drugs of plant origin has occupied the interest of researchers to focus on finding substances with pharmacological activity on diseases of various kinds. The seed of papaya (Carica papaya L.) combined with thyme administered orally, to which (Caviaporcellus) is an alternative dewormer (Pazmiño, 2017).

Recent research has found that the essential oils of plants belonging to the Labiatae Family, such as Thymus vulgaris and Oreganum vulgare, are rich in thymol and have insecticidal, fungicidal and bactericidal properties for use in the control of agricultural pests and diseases. They are also used in human and veterinary medicine for their beneficial effects on health and also as flavorings and preservatives of food, which guides us to the importance of cultivating and managing those species that have medicinal, nutritional and pesticide value (Cano, 2001).

A considerable number of investigations have shown that the essential oils of Thymus vulgaris are capable of inhibiting and controlling the proliferation of various microorganisms, from causing food rot, and tooth decay (Sartoratto 2004) to pathogenic microorganisms that cause gastrointestinal infections, respiratory (Husnu, et al., 2006) and skin (Sartoratto, et al., 2004).

Solano (2006) estimated an alternative treatment on bacterial pharyngotonsillitis caused by Streptococcus pyogenes using essential oil and infusion of Thymus vulgaris in vitro, obtaining optimal results that exceeded the bactericidal action of penicillin. Recalde (2018), on the other hand, evaluated the antimicrobial efficacy on Staphylococcus aureus demonstrating a high bactericidal efficacy in vitro using $1000 \mathrm{~g}$ of thymol in $1000 \mathrm{ml}$ of distilled water; the minimum bactericidal concentration that prevented the development of bacterial colonies was $1 \%$ while $30 \%$ concentrations totally inhibited bacterial growth.

The antimicrobial and antifungal activity of the essential oils of Thymus vulgaris and Oreganum vulgare has been investigated, demonstrating that thymol has antifungal activity against six 
strains of fungi that cause athlete's foot (Trichophyton rubrum), ringworm on the scalp (Trichophyton tonsurans and Microsporumgypseum), dermatophytosis of skin and nails (Tricophyton mentagrophytes), dermatophytosis in dogs (Microsporumcanis), tinea cruris (Epidermophyton floccosum) and onychomycosis (Guerra, 2011). The most favorable results for fungicidal and fungistatic activity were obtained with thymol in a concentration of $25 \mathrm{mg} / \mathrm{L}$ (Balanta, 2013).

Coon (1974) argues that the cempoalxóchitl; cempasúchil or cempaxochitl (Tageteserecta) is a plant that shows insecticidal and nematicidal qualities, because of the irritating oils that also give it pungent odor. Neher (1968) points out that the plant has been used in Mexico years ago to remove ticks and lice, since the content of a-tiertihenyl has been proven as the main nematicidal component of the plant. On the other hand, it has also been used as a pigment for poultry products due to the high content of xanthophylls, zeaxanthins and luteins present in the corollas; This pigment does not contribute to the nutritional value of the product or to the productive behavior of the birds (Martínez, 2004).

Allium sativus garlic, belonging to the Liliaceae family, has also been used as an alternative to growth promoters in broiler chickens, reporting that the inclusion of $1 \%$ garlic extract in the drinking water in broiler chickens exerts an effect on the health of the intestinal mucosa (Botía and Hortúa, 2013).

Mixtures of essential oils of thymol and carvacrol have been evaluated for the control of ectoparasites in plants such as corn and roses; in maize it has been used to combat the weevil (Sitophilus zeamais) and as a result of the treatment, repellency showed up to $73 \%$ at 72 hours in addition to corn seeds showed high percentages of germination without damaging the physiological quality (Cristobal, 2013). In roses, an acaricide based on essential oil of Thymus vulgaris has been formulated at $1.6 \%$ concentration to combat the red spider mite (Tetranychusurticae), generating levels of in vitro mortality of the mite of $96.7 \%$ at 24 hours after treatment and $100 \%$ at 48 hours, similar to those produced by commercial synthetic acaricides (Yañez, 2014).

In animals it has been used for the control of ectoparasites such as varroasis in bees using a gel with $12.5 \mathrm{~g}$ of thymol in $50 \mathrm{~g}$ of gel; the results showed that the application of a tray of gel with repetition after 15 days, allows to eliminate $95 \%$ of the varroa present in the colonies of honey bees under tropical conditions in Yucatan, Mexico (May-Itza, 2007). In Chiapas, a treatment with $8 \mathrm{~g}$ of thymol in $12 \mathrm{~g}$ of gel and $12 \mathrm{~g}$ of thymol in $8 \mathrm{~g}$ of gel with a total weight of $20 \mathrm{~g}$ each was carried out, presenting an efficiency similar to synthetic commercial products with the difference that the Thymol is more economical and does not leave toxic residues in honey (Abarca, 2001).

\section{CONTROL OF PARASITES IN POULTRY PRODUCTION}

Among the main effects that we can highlight of the essential oils in the production of birds, is that they improve the digestibility of nutrients, increase the production of digestive enzymes (lipases, amylases, trypsin), increase the nitrogen retention, have an antioxidant and antiinflammatory action, stimulate the non-specific immune system, increasing the production of 
macrophages and lymphocytes and also have an antimicrobial, antifungal, antiparasitic and antiprotozoal effect (Alesòn, 2009).

The nematicidal and bactericidal effects of medicinal plants such as Spanish oregano (Plectranthusamboinicus) administered to backyard birds infused with $10 \mathrm{~g}$ of fresh leaves in 90 $\mathrm{mL}$ of drinking water, adding $1 \mathrm{~mL}$ per liter of drinking water, have been evaluated. in birds, observing that it induces a reduction in the number of enterobacteria (Chuchuca, 2015) and mountain oregano (LippiaoriganoidesKunth) in which the supplementation of $100 \mathrm{ppm}$ of essential oil in broilers reduced the negative impact on oocysts. Eimeria spp. (Betancourt, 2012). Nematicidal effects of plants such as epazote (Chenopodium ambrosioides) have been found in fighting cocks (Álvarez, 2011).

The natural products including thyme (Thymus vulgaris) are considered first order as an antimicrobial (WHO, 1999) and phytobiotic of natural origin to replace the chemicals, because they have been positive without any toxic effect in the production of birds with different zootechnical purposes (Alesón, 2011).

Works carried out in different countries have used the essential oil of Thymus vulgaris for backyard birds and broiler chickens. Remmalet al., (2013) found that in vitro concentrations of 0.3 to $20 \mathrm{mg} / \mathrm{ml}$ serve as treatment and control of parasites of Eimeria spp.

In Ecuador, Thymus vulgaris powder was proven as a growth promoter in backyard birds, adding $350 \mathrm{mg}$ of ginger Zingiberofficinale in the feed of backyard birds (Toalombo, 2017). Eubiotic products have also been developed with mixtures of essential oils such as thymol, eugenol and piperine which generate a healthy balance of the microbiota in the intestinal tract of birds, which allows them to express their genetic potential and as such DSM Nutritional Product $®$ has patented a new eubiotic product based on essential oils and benzoic acid, obtaining as a result an increase in weight gain of up to $3 \%$ and an improvement in the conversion rate of $1.5 \%$. (Alesón, 2011).

\section{LEARNED LESSONS}

It is expected that with the application of Thymol in backyard chickens the presence of coccidia is null, given the review that has been made in this regard and that several authors reveal that its application in various mammals, and poultry and breeding semi industrial birds, has completely eradicated the presence of coccidia, so this work would complete the space in the local knowledge so that it can be applied in different ways, either in diluted dose in water, either in food or in the form of an attenuated agent, in such a way that the final recommendation would be for the owners of this bird, and they could consume it safely or commercialize it without representing a public health danger.

The value of medical herbalism in the state of Chiapas lies in the fact that it is a form of health care in which they trust and to which they resort on a daily basis to large sectors of the population; In addition to being accessible, it is a culturally legitimized practice.

\section{REFERENCE}


1. AdnaneRemmal, Sanaa Achahbar, Latifa Bouddine, Fouzia Chami and Najat Chami 2013, "Oocysticidal Effect of Essential Oil Components against Chicken Eimeria Oocysts" In International Journal of Veterinary Medicine: Research \& Reports, Vol. 2013 (2013), Article ID 599816, DOI:10.5171/2013.599816. Consultado el 16 de mayo de 2018 en: http://ibimapublishing.com/articles/IJVMR/2013/599816/599816.pdf

2. Abarca Cortés L. A. (2001). Uso de timol en gel para el control de varroa destructor, parasito de la abeja Apis mellifera, en tres altitudes, del estado de Chiapas, México. Universidad Autonoma de Chiapas.Facultad de Ciencias Quimicas.Tapachula de Córdova y Ordóñez, Chiapas, 33.

3. Agricultura, O. d. (2016). Producción y productos avícolas. Recuperado el 28 de Marzo de 2019, de http://www.FAO.org/poultry-production-products/production/es/

4. Alesón, A. M. (2011). Eubióticos su influencia en la sanidad intestinal de las aves. DSM Nutritional Products: Selecciones avicolas .Recuperado de:https://seleccionesavicolas.com/pdf-files/2011/9/6288-eubioticos-su-influencia-en-lasanidad-intestinal-de-las-aves.pdf

5. Alesón, R. M. (2009). Aceites esenciales y ácidos orgánicos: Beneficios productivos y sanitario de las aves. DSM Nutricional Products: Selecciones avicolas.

6. Alcaíno H., J. P. (2002). Coccidiosis Aviares de gallineros industriales de Chile. Chile: Universidad de Chile

7. Àlvares, C. (2011). Efecto del Extracto de Paico (Chenopodium ambrosioides) en parasitos gastrointestinales de gallos de pelea. Tunja-Boyacà: Cultura Cientifica JDC

8. Balanta, J. F. (2013). Caracteristicas fisicoquimicas y actividad antimicòtica del extracto de tomillo sobre cepas Fusarium oxysporum. Universidad Santiago de Cali: Facultad de ingenieria

9. Betancourt Liliana, A. N. (2012). Efecto de diferentes niveles de aceites esnciales Lippia origanoides kunth en pollos de engorde. MVZ. Còrdoba, 3033-3040.

10. Botía Carreño W.H., Hortúa Lopez L.C(2013). Extracto de ajo como alternativa a los promotores de crecimiento en pollos de engorde. Paipa, Boyacà, Colombia: Conexiòn Agropecuaria JDC.

11. Cano Morales T.M. (2001) Obtención y caracterización del aceite esencial de tomillo (thymus vulgaris) cultivado en Guatemala, utilizado en diversidad de productos fitofarmacéuticos. Guatemala. Universidad de San Carlos de Guatemala. Recuperado de: http://digi.usac.edu.gt/bvirtual/informes/puidi/INF-2001-075.pdf

12. Campoverde, P. N. (2011). Evaluacion de la actividad antimicrobiana de los aceites esenciales de orgenao (Oruganum vilgare L.) y tomillo ( Thymus vulgaris L.) como potenciales bioconservadores en carne de pollo. Riobamba, Ecuador: Escuela Superiro Politecnica de Chimborazo, Facultad de Ciencias, Escuela de Bioquimca y Farmacia

13. Cristobal Hernandez C. (2013). Control de Sitophilus zeamais, utilizando mezclas de timol y carvacrol en difrentes dosis en semilla de maiz almacenada y su efecto en la calidad fisologica. Buenavista Saltillo,Coahuila, Mèxico . Universidad Autonoma Agraria Antonio Narro.

14. Coon, N. 1974. The dictionary of uselul plants. RodalePress. Emmaus, Pa. USA

15. Del Cacho, E., 2013. Coccidiosis: La enfermedad, consecuencias y tratamiento. Facultad de Veterinaria, Departamento de Patología Animal, .Congreso científico de avicultura 177, 
Vol. 4, No. 04; 2019

ISSN: $2456-8643$

5001-Zaragoza, España. Recuperado de: http://www.wpsaaeca.es/aeca_imgs_docs/20_21_40_coccidiosis.pdf

16. Garcìa, R. M. (2008). Mecanismos de acciòn antimicrobiama de timol y carvacrol sobre microorganismos de interes en alimentos. Puebla: Departamento de ingenieria quimica y alimentos, Universidad de las Amèricas, Puebla.

17. Servicio de Información Agroalimentaria y Pesquera (SIAP) 2019. Recuperado de: http://infosiap.siap.gob.mx/repoAvance siap gb/pecAvanceEdo.jsp

18. Solano, E. (2006). Efecto de aceite esencial, infuiòn y extracto de etanol de Thymus vulgaris in vitro sobre un grupo de A-B hemolytic Streptococcus pyogenes. Mèxico: Revista Especializada en Ciencias Quimico Biològicas.

19. Toalombo P. Villafuerte A. (2017). Polifenoles del Tomillo (Thymus vulgari) y jengibre (Zingiber officinales) en la alimentacion de gallinas de campo. Actas iberoamericanas en conservacion animal, Escuela Superior Polietecnica de Chimborazo. Facultad de Ciencias Pecuarias.Carrera de Zootecnia, Ecuador. 88-93.

20. Torres C, Z. M. (2002). Antibioticos como promotores del crecimiento en animales . Grac Sanit, 109-112.

21. UNA. (2016). Indicadores Económicos. México, D.F.: Unión Nacional de Avicultores.Recuperado de:http://una.org.mx/index.php/component/content/article/2uncategorised/19-indicadores-economicos

22. Guerra Boone L. (2011). Evaluacion de la actividad antimicrobiana y antioxidante de acites esnciales de plantas usadas en medicina tradicional . Nuevo Leòn : Universidad Autonoma de Nuevo Leòn .Recuperado de:http://eprints.uanl.mx/2455/

23. Guevara H. F.,Rodríguez L. L., Perezgrovas G R., Gómez C. H., Pinto R. R., Rodríguez G. G., Hernández L. A., Medina J. F. J. y Nahed T. J. 2014. Crianza de gallinas de traspatio en La Frailesca chiapaneca: estrategia para la seguridad alimentaria. En: Gallinas criollas y guajolotes nativos de México. Universidad Autónoma de Chiapas.

24. Husnu Can Baser K (2006)) "El tomillo una alternativa terapéutica dental en la halitosis". México. UNAM. recuperado de: http://www.remeri.org.mx/tesis/INDIXETESIS.jsp?search $=$ unam\&ind $=11801 \&$ step $=25 \&$ order $=3 \&$ asc $=1$

25. May-Itza, W. d. (2007). Eficacia de un gel a base de timol en el control del àcaro Varroa destructor que infecta colonias de abejas Apis mellifera, bajo condiciones tropicales en Yucatàn, Mèxico. Distrito Federal, Mèxico: Unversidad Nacional Autònoma de Mèxico.

26. Neher, R. T. 1968. The ethnobotany of Tagetes. Econ. Sot. 317-325.

27. OMS (1999). Who monographs on selected meicinal plants Volume 1. Organizacion Muandial de la Salud Geneva, 289.

28. Organización de las Naciones Unidas (2019). Producccion y productos avícolas. Recuperado de:http://www.FAO.org/poultry-production-products/es/

29. Paredes Acosta, Olga Maribel (2015). Evaluación del efecto de un desparasitante natural a base de tomillo Thymus vulgaris en aves de traspatio en el cantón Salcedo parroquia Antonio José Holguìn. Carrera de Medicina Veterinaria y Zootecnia. UTC. Latacunga. 71 p. Recuperado de:http://repositorio.utc.edu.ec/handle/27000/2843 
29. Pazmiño, O. I. (2017). Desparasitante a base de semilla de papaya ( Carica papaya) y extracto de tomillo (Thymus vulgaris) para el control de coccidiosis en cuyes ( Cavia porcellus). Tulcàn, Ecuador: Universidad Politècnica Estatal del Carchi.

30. Peña, M. M. (7 de Julio de 2003). Evaluacion de tres niveles de pigmento de flor de Cempasuchil (Tagetes erecta) sobre la pigmentacion de la piel en pollos de engorde. (I. y. Centro de Enseñanza, Ed.) Mexico, D.F.

31. Ramirez, A. E. (1987). Origen, naturaleza y usos del cempoalxòchitl. Departamento de Ciencias Naturales, Universidad de Quintana Roo, 180-189.

32. Recalde, M. M. (2018). Eficacia antimicrobiana del aceite esncial de tomillo (Thymus vulgaris) sobre una cepa de Staphylococcus aureus. Tungurahua, Ecuador: Rev Inv Vet Perù.

33. Remmal, A. (2013). Oocusticial Effect of essencial oil components against chicken eimeria oocysts. international journal of veterinary medicine.

34. Roberts V. (2013) Las causas, signos clínicos y control de la coccidiosis en parvadas pequeñas de aves (gallinas, pavos, patos, gansos y faisanes) recuperado de:http://www.elsitioavicola.com/articles/2391/enfermedades-de-avicultura-de-traspatioparte-3-control-de-la-coccidiosis/

35. Rodriguez A. M., A. M. (2012). Procedimientos para la extraccion de aceites esenciales en plantas aromàticas . Proyecto SAGARPA-CONACYT, 47.

36. Ruiz H., Ruiz B., Mendoza N.P. 2014. Caracterización del sistema de producción de aves de traspatio del municipio de Pantepec, Chiapas. Rev. Actas Iberoamericanas de Conservación Animal. Vol 4. Pág. 41-43.

37. Sartoratto (2004). "El tomillo una alternativa terapéutica dental en la halitosis". México. UNAM. Recuperado de:

http://www.remeri.org.mx/tesis/INDIXTESIS.jsp?search=unam\&ind=11801\&step=25\&order=3 $\underline{\text { \&asc }}=1$

39. Yañez M. Patricio (2014). Comparcion de la actividad acaricida de los aceites esenciales de Ocinum basilicum, Coriandrum sativum y thymus vulgaris contra Tetrannychus urticae. $L a$ Granja: Ciencias de la vida,Universidad Politecnica Salesina. Quito, Ecuador 21-33.

40. Zaragoza L., B. Martínez, A. Méndez, V. Rodríguez, J. S. Hernández, G. Rodríguez y R. Perezgrovas. 2011. Avicultura familiar en comunidades indígenas de Chiapas, México. Actas Iberoamericanas de Conservación Animal, vol.1(2011):411-415 